\title{
Transgenic Expression of Pear PGIP in Tomato Limits Fungal Colonization
}

\author{
Ann L. T. Powell, ${ }^{1}$ Jan van Kan, ${ }^{2}$ Arjen ten Have, ${ }^{2}$ Jaap Visser,${ }^{3}$ L. Carl Greve, ${ }^{4}$ Alan B. Bennett,${ }^{1}$ \\ and John M. Labavitch ${ }^{4}$ \\ ${ }^{1}$ Department of Vegetable Crops University of California, Davis 95616-8631, U.S.A.; ${ }^{2}$ Laboratory of \\ Phytopathology, Wageningen University, Wageningen, The Netherlands; ${ }^{3}$ Section Molecular Genetics of \\ Industrial Microorganisms, Wageningen University, Wageningen, The Netherlands; ${ }^{4}$ Department of \\ Pomology, University of California, Davis 95616-8631, U.S.A. \\ Accepted 12 May 2000.
}

\begin{abstract}
Transgenic tomato plants expressing the pear fruit polygalacturonase inhibitor protein (pPGIP) were used to demonstrate that this inhibitor of fungal pathogen endopolygalacturonases (endo-PGs) influences disease development. Transgenic expression of pPGIP resulted in abundant accumulation of the heterologous protein in all tissues and did not alter the expression of an endogenous tomato fruit PGIP (tPGIP). The pPGIP protein was detected, as expected, in the cell wall protein fraction in all transgenic tissues. Despite differential glycosylation in vegetative and fruit tissues, the expressed pPGIP was active in both tissues as an inhibitor of endo-PGs from $\mathrm{Bo}$ trytis cinerea. The growth of $B$. cinerea on ripe tomato fruit expressing pPGIP was reduced, and tissue breakdown was diminished by as much as $15 \%$, compared with nontransgenic fruit. In transgenic leaves, the expression of pPGIP reduced lesions of macerated tissue approximately $\mathbf{2 5 \%}$, a reduction of symptoms of fungal growth similar to that observed with a $B$. cinerea strain in which a single endo-PG gene, Bcpg1, had been deleted (A. ten Have, W. Mulder, J. Visser, and J. A. L. van Kan, Mol. PlantMicrobe Interact. 11:1009-1016, 1998). Heterologous expression of pPGIP has demonstrated that PGIP inhibition of fungal PGs slows the expansion of disease lesions and the associated tissue maceration.
\end{abstract}

Additional keywords: Lycopersicon esculentum, plant defenses, reducing sugar assay.

Plant-pathogenic bacteria and fungi must penetrate the plant cell wall in order to initiate and expand necrotic infections or to establish colonization sites for biotrophic infections within the plant. Many hydrolytic enzymes produced by fungal pathogens attack the nutrient-rich polymers that constitute the

Corresponding author: Ann L. T. Powell, Mann Laboratory, Department of Vegetable Crops, University of California, One Shields Avenue, Davis 95616, U.S.A.; Telephone: 1-530-752-9096; Fax: 1-530-7524554; E-mail: alpowell@ucdavis.edu

This research was supported in part by the USDA (NRICGP 93-373039004) and a grant from the California Tomato Board. The research also was partly supported by the Dutch Technology Foundation (grant WBI33.3046). plant cell wall (Elad and Evensen 1995). Among the cell-walldegrading activities produced by phytopathogens are endoand exo-polygalacturonases (PGs), pectate lyases, and glucanases. Inhibitors of fungal enzymes that degrade plant cell walls have been proposed to be part of the plant defenses that limit the development of disease symptoms caused by microbial pathogens (Cervone et al. 1989; Stotz et al. 1993, 1994). Polygalacturonase inhibitor proteins (PGIPs) are glycoproteins located in plant cell walls that specifically inhibit fungal PGs, especially those with mixed endo/exo functions (Cook et al. 1999). PGIPs have been identified in nearly all plants in which they have been sought.

A role for PGIPs in a plant's defense against fungal pathogens is suggested by four observations. First, PGs are produced early in plant-fungus interactions and contribute to the expansion of the infection site, although they may not be necessary for infections of all tissues (ten Have et al. 1998). Second, PGIPs can inhibit some, but not all, fungal PGs in vitro (Yao et al. 1995; Sharrock and Labavitch 1994), especially those from the least aggressive pathogens, suggesting a correlation between the in vitro inhibition of PGs by PGIPs and their in planta function (Abu-Goukh et al. 1983). Third, the PGs inhibited in vitro by PGIPs produce small quantities of polygalacturonic acid oligomers (Cervone et al. 1989) that can induce some defense responses when applied exogenously to plant cells (Darvill et al. 1992). Finally, PGIPs share with plant resistance gene products a structural motif, the leucinerich repeat (LRR) sequence motif (De Lorenzo et al. 1994; Stotz et al. 1994), that is necessary for genotype-specific pathogen resistance (Staskawicz et al. 1995; Baker et al. 1997). If the PGIP's function in the plant is to limit fungal PG activity, then one would expect that plant tissue maceration and necrosis by the pathogen would be altered as a consequence of changing the PGIPs in the plant.

Endo-PGs of Botrytis cinerea appear to contribute to the fungal invasion and degradation of host tissues. B. cinerea secretes a large number of PG isozymes (Leone 1990; Johnston and Williamson 1992; Van der Cruyssen et al. 1994). Two purified and partially characterized PGs have pIs of 8.8 and 4.9 and apparent molecular masses of approximately 36 $\mathrm{kDa}$. Recent molecular genetic studies have identified a PG gene family consisting of six members (Wubben et al. 1999). Phylogenetic analysis indicated that the genes are distributed 
over at least three distinct monophyletic groups (Wubben et al. 1999) and exhibit differential expression in vitro in response to different carbon sources (Wubben et al. 2000). Mutation of one member of the PG gene family, Bcpgl, resulted in a significant reduction of virulence on tomato leaves and fruit, as well as on apple fruit (ten Have et al. 1998), providing for the first time functional evidence that an endo-PG contributes to virulence of a plant pathogen.

The endo-PG activity of $B$. cinerea is, at least partially, inhibited in vitro by PGIPs from raspberry, pear, tomato, and apple fruit and Phaseolus vulgaris hypocotyl tissue (Toubart et al. 1992; Johnston et al. 1993, 1994; Sharrock and Labavitch 1994; Stotz et al. 1994; Yao et al. 1995; Leckie et al. 1999). However, PGIPs from different plants and tissues do not inhibit fungal PGs equally (Desiderio et al. 1997; Cook et al. 1999). Specific amino acids in the exposed $\beta$ strand in the central part of the PGIP LRR determine the PG recognition and inhibitor specificity of two P. vulgaris PGIPs (Leckie et al. 1999).

Because pathogen endo-PGs can contribute to fungal virulence, we evaluated whether expression of a heterologous PGIP would confer increased resistance toward $B$. cinerea. In tomato the mRNA for the endogenous PGIP (tPGIP) is expressed in immature fruit (Stotz et al. 1994); the abundance of this mRNA decreases as the fruit ripen, and is not detected in vegetative tissues, even after wounding. In vitro, a pear fruit PGIP (pPGIP) inhibits $B$. cinerea PGs more than tPGIP does (Stotz et al. 2000). Therefore, to test the hypothesis that increased expression of PGIP in plants causes reduced symptoms of fungal disease or limited tissue maceration, we expressed pPGIP constitutively in tomato (Powell et al. 1994). After inoculations of leaves by one strain of $B$. cinerea and a PG mutant of that strain and ripe fruit by another strain of $B$. cinerea, we looked for differences in the progression of disease symptoms on transgenic and control plants. Here we show that the initial establishment of $B$. cinerea infection occurs in tissues of these transgenic plants, but the expanding area of macerated lesions is reduced both in fruit and in leaves, compared with infections of control plants.

\section{RESULTS}

Tomato fruit PGIP is expressed early in fruit development.

Tomato fruit PGIP ( $t P G I P$ ) mRNA can be detected in fruit tissues that have not been exposed to fungal pathogens and tPGIP mRNA is most abundant in the youngest developing fruit (Fig. 1). Hybridization of a $t P G I P$ probe to RNA from tomato fruit collected throughout development and ripening demonstrates that $t P G I P$ mRNA abundance decreases approximately 20 -fold as the fruit develop from $1.5-$ to $2.5-\mathrm{cm}$ diameter fruit to mature green fruit. Although the amount of the $t P G I P$ mRNA increases slightly at the pink stage, it continues to decrease substantially as the fruit ripen further. Previous analysis has shown that $t P G I P$ mRNA is at least 200fold less abundant in stem tissue than in mature green fruit (Stotz et al. 1994).

\section{Pear fruit PGIP is expressed in transgenic tomato.}

The coding sequence for the pear fruit PGIP ( $p$ PGIP; Stotz et al. 1993) was introduced into tomato cotyledon explants to obtain transgenic plants that accumulate pPGIP in all tissues and throughout development and fruit ripening. The $35 \mathrm{~S}$ promoter of Cauliflower mosaic virus (CaMV) and the $\mathrm{U} 1 \Omega$ translational enhancer of Tobacco mosaic virus (TMV) (Gallie et al. 1987) regulated $p P G I P$ expression. Transgenic plants expressing pPGIP were morphologically indistinguishable from untransformed tomato plants (Powell et al. 1994). Primary transformants with single insertions of the chimeric $p P G I P$ transgene were allowed to self-pollinate and homozygous, heterozygous, and untransformed, segregating progeny were selected. Siblings in which the single-copy transgene had segregated and was not detected were used as untransformed, segregating controls.

Hybridization analysis of total RNA from vegetative tissues and from developing and ripening fruit demonstrated that pPGIP mRNA was expressed abundantly and uniformly in the transgenic plants (data not shown) and no message closely homologous to $p P G I P$ was expressed in nontransgenic plants. Subsequent hybridization of the same blots with a $t P G I P$ probe showed that the amount of the endogenous $t P G I P$ mRNA was very similar in comparable tissues from transgenic and control plants (Fig. 2). The results demonstrate that no other PGIP closely related to $t P G I P$ is induced by the heterologous expression of $p P G I P$.

Transgenic pPGIP protein was produced abundantly in vegetative and fruit tissues of the transgenic plants. Preparations of proteins showed pPGIP in all tissues (Fig. 3). The abundant and heterogeneous, approximately $45 \mathrm{kDa}$, protein visible with Coomassie blue staining (Fig. 3A) was recognized by the pPGIP antibodies raised against deglycosylated pPGIP purified from pear fruit (Stotz et al. 2000) on a Western blot (immunoblot) of a similar gel (Fig. 3B).

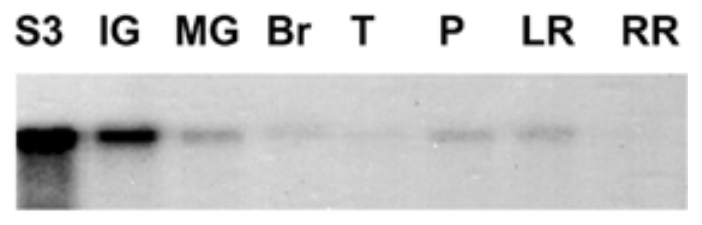

Fig. 1. Tomato PGIP expression in tomato fruit. A Northern (RNA) blot with $15 \mu \mathrm{g}$ of total RNA from stage 3 (1.5- to 2.5-cm-diameter, S3), immature green (IG), mature green (MG), breaker $(\mathrm{Br})$, turning $(\mathrm{T})$, pink (P), light red (LR), and red ripe (RR) stages of T5 tomato fruit was hybridized to a ${ }^{32} \mathrm{P}$ random prime-labeled tPGIP probe. After being washed twice for $30 \mathrm{~min}$ in $1 \times \mathrm{SSC}(1 \times \mathrm{SSC}$ is $0.15 \mathrm{M} \mathrm{NaCl}$ plus $0.015 \mathrm{M}$ sodium citrate), $0.1 \%$ sodium dodecyl sulfate (SDS) at $42^{\circ} \mathrm{C}$, the blot was exposed to X-OMAT film for $16 \mathrm{~h}$.

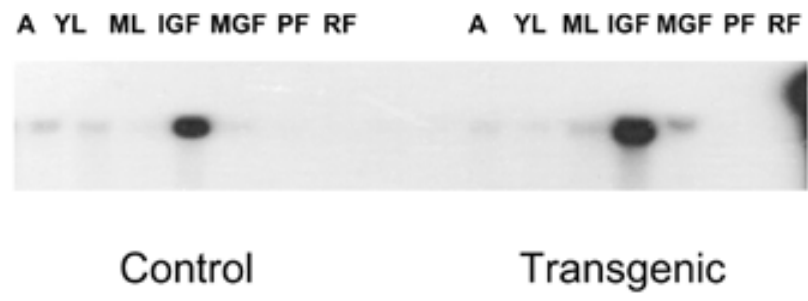

Fig. 2. Expression of $t P G I P$ in control and transgenic plants. RNA was prepared from untransformed segregant control (2-3-34) and homozygous transgenic (2-3-11) plants. A Northern (RNA) blot with $20 \mu \mathrm{g}$ of total RNA from the apex (A), young leaves (YL), mature leaves (ML), immature green fruit (IGF), mature green fruit (MGF), pink fruit (PF), and red ripe fruit (RF) was hybridized to a ${ }^{32} \mathrm{P}$ random prime- labeled tPGIP probe. The blot was washed twice for $20 \mathrm{~min}$ in $0.2 \times \mathrm{SSC},(1 \times \mathrm{SSC}$ is $0.15 \mathrm{M}$ $\mathrm{NaCl}$ plus $0.015 \mathrm{M}$ sodium citrate) $0.1 \%$ sodium dodecyl sulfate (SDS) at $42^{\circ} \mathrm{C}$ and exposed to X-OMAT film for $20 \mathrm{~h}$ with each probe. 


\section{Transgenic pPGIP produced in tomato is modified after translation.}

Protein extracts from vegetative and fruit tissues contained approximately the same proportion of transgenic pPGIP (see Figure 3B). Compared with the amount of pPGIP extracted

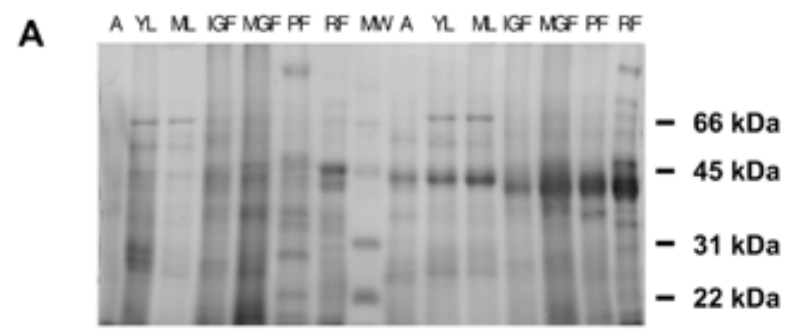

B

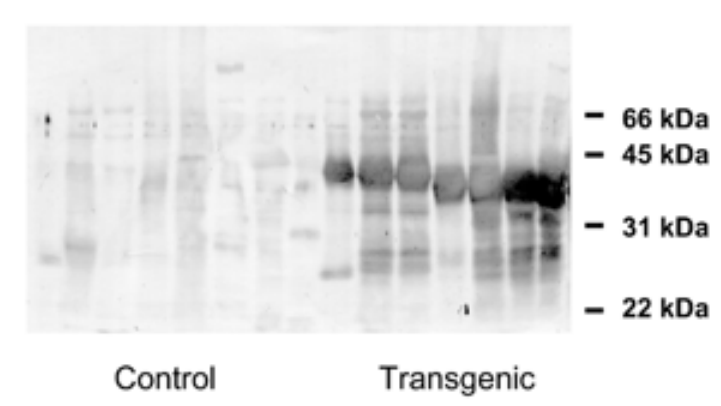

Fig. 3. pPGIP protein in control and transgenic plants. Proteins were extracted with $1 \mathrm{M} \mathrm{NaCl}, 0.1 \mathrm{M} \mathrm{NaAcetate}$ at $\mathrm{pH} 6$ from untransformed segregant control (plant 2-3-34) and homozygous transgenic (2-3-11) plants. Total protein $(50 \mu \mathrm{g})$ from ripe fruit $(\mathrm{RF})$, pink fruit $(\mathrm{PF})$, mature green fruit (MGF), immature green fruit (IGF), mature leaves (ML), young leaves (YL), and the apex (A) were separated on a $10 \%$ acrylamide gel by sodium dodecyl sulfate-polyacrylamide gel electrophoresis (SDS-PAGE). Protein gel was (A) stained with Coomassie Blue or (B) transferred to a membrane for detection by polyclonal antibodies to deglycosylated pPGIP. Molecular masses, in $\mathrm{kDa}$, based on standards (MW) are indicated. from green fruit, about 10 to 15 times more pPGIP was extracted from leaves per gram fresh weight tissue. The water content of the fresh leaf and fruit tissues probably accounts for most of this apparent difference in pPGIP accumulation.

Transgenic pPGIP behaves as a protein that is localized in the apoplast as is the endogenous tPGIP. pPGIP can be obtained by vacuum infiltration of leaf and fruit pericarp tissues, and on Western blots this protein appears to be the same as the pPGIP obtained by homogenization of transgenic tissues. Transgenic pPGIP is secreted into the extracellular medium by cells growing as suspension cultures established from a homozygous transgenic plant (2-3-11). pPGIP in the suspension culture medium forms a single $45-\mathrm{kDa}$ band on Western blots of denaturing sodium dodecyl sulfate-polyacrylamide gel electrophoresis (SDS-PAGE) gels.

Although transgenic pPGIP is produced in vegetative and fruit tissues, the protein apparently is glycosylated differently in the two tissues. Western blot analysis of proteins extracted from leaves demonstrates that the denatured pPGIP glycoprotein on SDS-PAGE is a single $45-\mathrm{kDa}$ species but pPGIP from tomato fruit forms multiple bands between 41 and $43 \mathrm{kDa}$ (Fig. 4A). pPGIP in homogenates from transgenic stem tissue and ripe fruit resembles pPGIPs from leaves and green fruit, respectively. When equivalent amounts of glycosylated pPGIP as recognized by the pPGIP antibodies are compared by radial diffusion assays of inhibitor activity (Taylor and Secor 1988), the transgenic pPGIP from leaves is approximately two to five times more active than the pPGIP from tomato fruit.

Protein extracts of pericarp fruit tissue from the homozygous progeny of the primary transformants contain five- to 10fold more PGIP activity than similar extracts from nontransgenic plants when assayed by the radial diffusion of fungal PGs in gels containing the PG substrate, citrus polypectate. A five- to 10-fold increase in inhibitor activity in transgenic red fruit also was observed in assays of the reducing sugar

\section{A $\quad$ B}

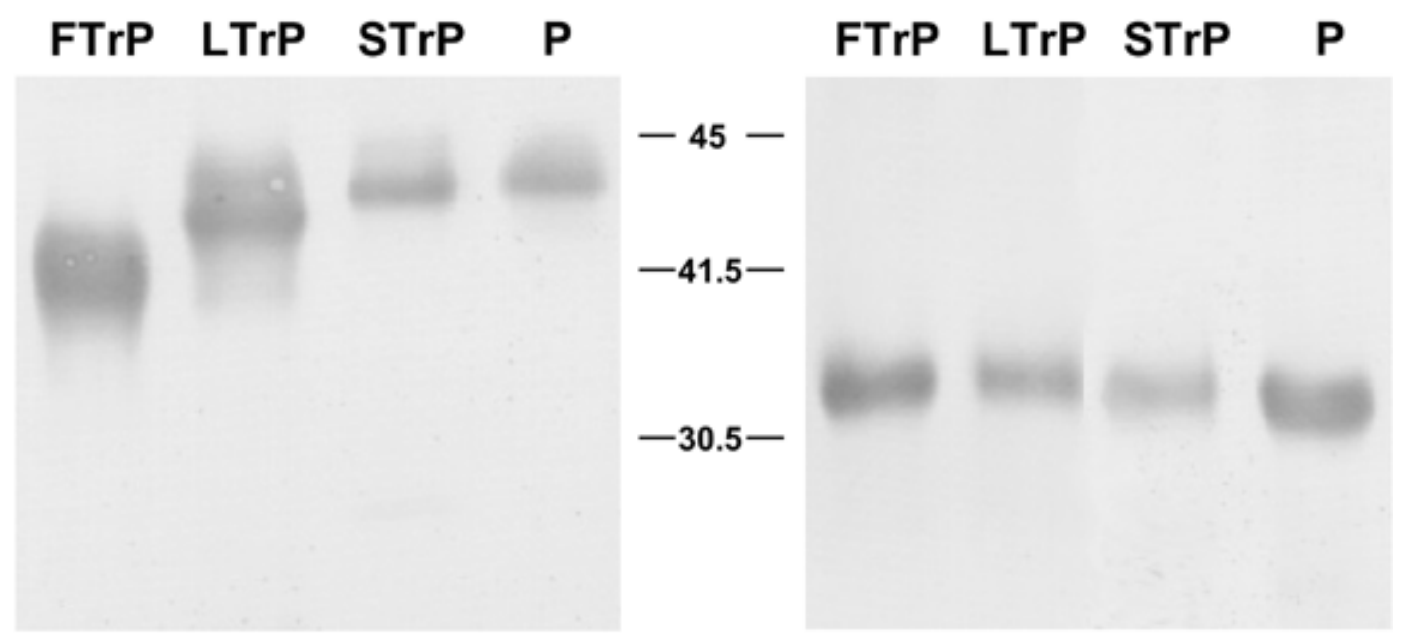

Fig. 4. Deglycosylation of pPGIP. Partially purified pPGIP was chemically deglycosylated by TFMS and visualized by Western blots (immunoblots) made from sodium dodecyl sulfate-polyacrylamide gel electrophoresis (SDS-PAGE) with polyclonal antibodies to pPGIP. Partially purified pPGIP from pear fruit $(\mathrm{P})$, suspension cultures established from transgenic tomato over-expressing pPGIP (STrP), from leaves of transgenic tomato (LTrP), and from mature green fruit from transgenic tomato (FTrP) were observed (A) before and (B) after deglycosylation. Approximate positions of molecular masses $(\mathrm{kDa})$ are indicated. 
equivalents produced by inhibited fungal PGs in ripe fruit extracts heat treated to remove the endogenous fruit PG activity (Tucker et al. 1980). Heat treatment did not affect pPGIP activity since the inhibitor activity detected by radial diffusion assay was unchanged. Analysis of the inhibitor activity in leaf tissue showed that approximately 20- to 25 -fold more inhibitor activity was expressed in homozygous transgenic plants than in control, untransformed segregants. Since the total amount of pPGIP glycoprotein detected by pPGIP antibodies in extracts from leaves and fruit is approximately the same, this observation agrees with the estimate that the pPGIP in leaves is two to five times more active than in fruit. Suspension cultures established from transgenic plants secreted approximately 20 -fold more inhibitor activity than suspension culture lines established from control plants.

Chemical deglycosylation by TFMS (trifluoromethane sulfonic acid) of crude cell wall proteins indicated that deglycosylated proteins detected by pPGIP antibodies from leaf, green fruit, and suspension culture from transgenic plants and from pear fruit were identical on SDS-PAGE (Fig. 4B). Therefore, the heterogeneity of the transgenic pPGIP from leaves and fruit of the transgenic plants appears to be a result of differences in glycosylation of the protein in these tissues.

\section{Fruit from transgenic plants expressing $p P G I P$ exhibit enhanced resistance to colonization by $B$. cinerea var. Del 11.}

Four independent transgenic lines with single insertions of the transgenic pPGIP sequence were self-pollinated. Their progeny were classified as homozygous or heterozygous transgenic plants or untransformed segregant controls. Ripe fruit from these progeny grown in the greenhouse were inoculated with an aqueous suspension of $10^{3}$ fungal conidia from $B$. cinerea var. Del 11 into four or five small wound sites on each fruit. After 3 days in humid crispers at $15^{\circ} \mathrm{C}$, visual assessments of fungal growth and tissue maceration around the inoculation site were made. Fewer inoculation sites on fruit from transgenic plants showed tissue maceration because of fungal colonization, compared with fruit from control, untransformed, segregant plants (Fig. 5). Fruit from homozygous plants showed as much as a $15 \%$ reduction in symptoms, compared with the fruit from untransformed segregants lacking the transgenic pPGIP. When incubations were extended up to 7 days, fungal growth was observed in most of the inoculated sites on ripe fruit. Inoculation with $B$. cinerea var. Del 11 failed to result in reproducible lesion development on detached leaves.

Two-way analysis of variance (ANOVA) with the transgenic lines, the transgene copy number, and their interaction as sources of variance showed that pathogen susceptibility differences between the fruit from homozygous, heterozygous, and untransformed segregant plants were highly significant $(P$ $<0.003)$. Although the differences between the transgenic lines also were highly significant $(P<0.00001)$, these differences probably were due to positional and environmental variation. Because nonsignificant interactions between lines and copy number were measured $(P=0.61)$, Bonferroni's modified $t$ test supported the conclusion that significant differences between homozygous and untransformed, segregant progeny of the four transgenic lines were measured, but not between the heterozygous and either the homozygous or untransformed, segregating progeny.
Leaves from transgenic plants expressing pPGIP exhibit reduced fungal maceration.

Two homozygous transgenic lines, 2-16-27 and 2-3-11, and the corresponding untransformed, segregant, control lines, 216-14 and 2-3-34, were used for inoculations of vegetative tissue. Detached leaves were inoculated with conidial suspensions of the wild-type B. cinerea strain B05.10, or with the $\Delta B c p g 1$ mutant (ten Have et al. 1998). A small-scale experiment indicated that transgenic plants were susceptible to both strains of $B$. cinerea, at 4 and $20^{\circ} \mathrm{C}$, but that lesion growth at $4^{\circ} \mathrm{C}$ was slower on transgenic plants than on control plants. Larger scale experiments were conducted three times.

Leaves usually developed primary lesions at each inoculation site after overnight incubation at $20^{\circ} \mathrm{C}$ and subsequently many of the primary lesions expanded. Occasionally, inoculation sites on some of the leaflets did not develop a primary lesion, but this was not correlated to the expression of the transgene. No significant difference $(P>0.1)$ in the proportion of expanding lesions between control plants and transgenic plants incubated at $20^{\circ} \mathrm{C}$ was observed (Table 1).

At $4^{\circ} \mathrm{C}$, virtually all lesions on both control and transgenic plants expanded at a uniform rate that could be measured easily after 7 to 10 days. Figure 6 presents the results of inoculations of leaves incubated at $4^{\circ} \mathrm{C}$. On control plant leaves (left leaflets) the $\Delta B c p g l$ mutant strain (inoculated on the right halves of the leaflets) produced smaller lesions than those produced by the wild-type strain B05.10 (inoculated on the left half of the same leaflets). This result confirms that Bcpg1 is required for full virulence (ten Have et al. 1998). Also, on $p P G I P$-expressing plants (right leaflets), the $\Delta B c p g 1$ mutant strain (inoculated on the right halves of the leaflets) produced lesions that expanded more slowly than those produced by the wild-type B05.10 strain (inoculated on the left half of the right leaflets). The difference in the rate of expansion of the lesions between the wild-type and mutant $B$. cinerea strains was,

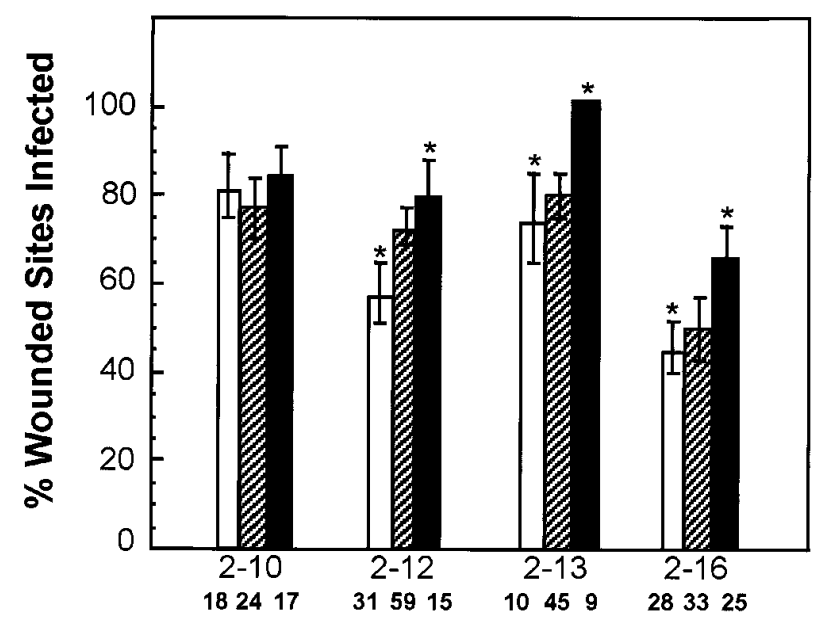

Fig. 5. Inoculation of ripe transgenic fruit with Botrytis cinerea. Ripe fruit from four lines of transgenic tomato progeny were inoculated with $10^{3}$ conidia of $B$. cinerea var. Del 11 in small puncture wounds. Number of sites with macerating fungal growth was assessed after 3 days in moist conditions at $15^{\circ} \mathrm{C}$. Total number of fruit inoculated is indicated below name of transgenic family. Results from homozygous individuals are expressed in the open bars, heterozygous individuals in crosshatched bars, and untransformed segregant individuals in solid bars. Standard errors of the means are represented by error bars. 
however, less pronounced on the transgenic plants than on the control plants. The lesions of both the wild-type and mutant strains on the transgenic plant were smaller and less transparent, and had a more turbid appearance than those on the control plant (Fig. 6). In vitro at $4^{\circ} \mathrm{C}, B$. cinerea $\mathrm{PGs}$ are approximately $25 \%$ as active as at $20^{\circ} \mathrm{C}$ and the $\mathrm{PG}$ activity at the lower temperature is completely inhibited by pPGIP in vitro (L. C. Greve, personal observation).

Results of three independent inoculation experiments incubated at $4{ }^{\circ} \mathrm{C}$ on leaves from plants grown in full summer (experiment 2), in autumn (experiment 3), and in spring (experiment 4) are summarized in Table 2. On leaves from transgenic plants, the wild-type strain produced lesions that were 12 to $24 \%$ smaller than those on leaves from the control plants. The $\Delta B$ cpgl mutant also produced smaller lesions on leaves from the transgenic plants than on the control plant leaves. The lesions produced by the $\Delta B c p g 1$ mutant strain on the $p P G I P$-expressing transgenic plants were 2 to $10 \%$ smaller than on the control plants, with an exceptional reduction of $22 \%$ (Table 2, Exp. 4, compare 86 vs $64 \%$ ).

Quantitative differences between lesions caused by the two fungal strains on each plant genotype were observed. On untransformed, segregant, control plants the $\Delta B c p g l$ mutant strain produced 14 to $32 \%$ smaller lesions than the wild-type strain, B05.10. On transgenic, PGIP-expressing plants, the lesions produced by the $\Delta B c p g 1$ mutant strain also were significantly smaller than those produced by the wild-type strain B05.10, in three out of six experiments. Within each experiment, the quantitative trends were similar for the transgenic lines, although the extent of lesion size reduction varied between experiments, possibly because of differences in the physiological status of the plants due to seasonal influences.

ANOVA indicated that within a set of data for an individual experiment, as well as in the compiled set of data for the three repetitions, the homozygous transgenic lines (2-16-27 and 2$3-11)$ are significantly more resistant $(P<0.0001)$ than the respective control lines (2-16-14 and 2-3-34). Moreover, within a data set of an individual experiment, as well as in the compiled data set of the three repetitions, the $\Delta B c p g 1$ mutant is significantly less virulent $(P<0.03)$ than the wild-type, confirming previous observations of ten Have et al. (1998).

\section{DISCUSSION}

Gray mold symptoms that develop when $B$. cinerea is grown on tissues of transgenic plants expressing pPGIP are less than those that develop on inoculated control plant tissues. This attenuation of disease symptoms indicates that PGIPs can modulate fungal pathogen maceration of plant tissues. The partial resistance of the leaves from transgenic plants suggests that inhibition of pathogen PGs does not prevent the establishment of the initial plant-pathogen interaction, but influences the subsequent expansion of the fungal mass. Reduction of plant tissue maceration and fungal lesion expansion is most pronounced at $4^{\circ} \mathrm{C}$, when the B05.10 strain of the fungus grows more slowly and attacks plant tissues less vigorously than at $20^{\circ} \mathrm{C}$. The observation that transgenic fruit are less susceptible to another strain of $B$. cinerea (Del 11) suggests that transgenic pPGIP in fruit may effectively inhibit at least some of the PGs produced by this strain of $B$. cinerea originally isolated from a fruit tissue, grape berries. The demonstration that fungal lesion expansion is reduced by pPGIPs expressed in plant tissues provides evidence that pathogen endo-PGs are relevant in the virulence of $B$. cinerea and that PGIPs in plant tissues can regulate the fungal PG activity during infection.

The $B$. cinerea endo-PG gene, Bcpgl, has been shown to be required for full virulence on tomato leaves; the $B$. cinerea mutant strain lacking Bcpgl grows less aggressively than the wild-type strain on nontransgenic tomato leaves (ten Have et al. 1998). The reduction of tissue maceration on leaves of transgenic pPGIP expressing plants inoculated with wild-type $B$. cinerea was similar to the attenuated development of disease by the $\Delta B c p g 1$ mutant strain on control plants. This similarity suggests that pPGIP inhibits BcPG1 and possibly some of the other PG isoforms produced by the wild-type fungus. In vitro, partially purified transgenic pPGIP can inhibit most of the PG activity secreted by the wild-type $B$. cinerea grown in culture conditions where BcPG1 is the primary PG produced (L. C. Greve, personal observation). However, other PG isoforms have been detected in protein extracts prepared from tomato leaf and fruit tissues inoculated with $B$. cinerea (A. Powell and K. Sharrock, personal observation). Other cell wall hydrolases including the other PG isoforms may account for the lesion formation that is seen on transgenic plants.

The endo-PG:PGIP interactions may be complex and several aspects of the potential interactions should be considered when the resistance assays are interpreted. First, B. cinerea synthesizes many PGs, but not all isoforms are inhibited by pPGIP in vitro (Sharrock and Labavitch 1994). Similar specificity of PG inhibition is expected to occur in planta. Furthermore, each fungal PG gene has different expression patterns in planta (A. ten Have, unpublished work) as well as in vitro (Wubben et al. 2000), and the encoded isozymes may have different biochemical characteristics. Second, it is not known whether sufficient pPGIP accumulates in the transgenic plant to maximally inhibit the endo-PGs in the infected plant tissues. Because the disease symptoms of the $\Delta B c p g 1$ mutant on control tomato leaves are comparable to the growth of wildtype $B$. cinerea on pPGIP-expressing tomato leaves, we have

Table 1. Expanding lesions at $20^{\circ} \mathrm{C}$ on transgenic and control plants inoculated with wild-type and mutant Botrytis cinerea strains

\begin{tabular}{|c|c|c|c|c|c|c|c|c|}
\hline \multirow[b]{2}{*}{ Experiment } & \multicolumn{2}{|c|}{ Control 2-16-14 ${ }^{a}$} & \multicolumn{2}{|c|}{ Transgenic 2-16-27 ${ }^{\mathrm{a}}$} & \multicolumn{2}{|c|}{ Control 2-3-34 ${ }^{a}$} & \multicolumn{2}{|c|}{ Transgenic $2-3-11^{a}$} \\
\hline & $\mathbf{W t}$ & $\Delta$ pg1 & Wt & $\Delta$ pg1 & $\mathbf{W t}$ & $\Delta$ pg1 & $\mathbf{W t}$ & $\Delta$ pg1 \\
\hline $\operatorname{Exp} 2(08 / 98)$ & $106(200)$ & $121(200)$ & $71(200)$ & $39(200)$ & $107(200)$ & $101(200)$ & $114(200)$ & $120(200)$ \\
\hline Exp $3(11 / 98)$ & 47 (160) & $47(160)$ & $25(160)$ & $23(160)$ & $108(160)$ & $83(160)$ & $94(160)$ & $85(160)$ \\
\hline Exp $4(05 / 99)$ & $32(70)$ & $38(70)$ & $35(70)$ & $53(70)$ & $50(90)$ & $52(90)$ & $37(90)$ & $41(90)$ \\
\hline
\end{tabular}

${ }^{a}$ Each leaf was inoculated on two leaflets. Each leaflet was inoculated on one half with the wild-type strain B05.10 (Wt) and on the opposite half with the Bcpg1 gene replacement mutant strain ( $\Delta \mathrm{pg} 1$, ten Have et al. 1998). Number of lesions expanding beyond inoculation site was determined 4 days post inoculation. Numbers in parentheses are total number of inoculation sites. 
concluded that pPGIP probably inhibits BcPG1 in vivo. Additional $B$. cinerea $\mathrm{PGs}$ also may be inhibited in planta because, on transgenic tomato leaves, the $\Delta B c p g 1$ mutant, which lacks $\mathrm{BcPG} 1$, is less aggressive than on control plant leaves in some of the experiments (see Table 2). Future characterization of the pathogen PG isoforms and their inhibition in planta will identify which PGs are produced and inhibited on control and transgenic tissues.

In addition to the endogenous $t P G I P$ expressed in immature fruit, tomato contains a second PGIP gene (A. Powell, D. Francis, and R. Chatelet, personal observation). The regulation of the expression and the specificity of PG inhibition by the PGIP encoded by this gene are not known, but it may contribute to the population of PGIPs in transgenic tomato plants. The collection of pathogen PGs and endogenous and transgenic PGIPs in the plant may lead to complex alterations of endo-PG function and PGIP expression, any of which could affect the size of lesions. If the transgenic pPGIP is sufficiently abundant to saturate all the fungal endo-PGs present in vivo and shown to be inhibited in vitro, wild-type $B$. cinerea lesions on transgenic plants would most likely not be reduced as much as lesions from a hypothetical mutant strain lacking all endo-PGs on nontransgenic plants. Such a mutant has, however, not been obtained thus far, and will be difficult to develop since $B$. cinerea contains a family of at least six endoPG encoding genes (Wubben et al. 1999). It is expected that some of the $B$. cinerea PGs in infected tissues are not inhibited in planta by the endogenous and heterologous PGIPs of the transgenic plants since not all $B$. cinerea $\mathrm{PGs}$ produced in vitro are inhibited by pPGIP (Sharrock and Labavitch 1994).

The expression of $p P G I P$ was controlled by a constitutive rather than a pathogen-inducible promoter in tomato plants to determine whether the heterologous pPGIP that accumulated prior to infection could contribute to pathogen defense. Abundant expression of $p P G I P$ in all tissues of the transgenic tomato lines resulted in the production of heterologous pPGIP glycoproteins whose activity and post-translational glycosylation differ in vegetative and fruit tissues. Apparently, the posttranslational glycosylation of the heterologous pPGIP in transgenic leaves and stems of tomato is similar to that of the endogenous pPGIP in pear fruit. In transgenic tomato fruit, however, pPGIP appears to have multiple glycosylated forms between 41 and $43 \mathrm{kDa}$ and, thus, is similar to the endogenous tPGIP in nontransgenic fruit (Stotz et al. 1994). The mechanism that allows for multiple glycosylated forms of the pPGIP in tomato fruit tissues but not in vegetative tissues is not apparent from these results. Because the pPGIPs from tomato leaves and fruit are not equally active fungal PG inhibitors, glycosylation of pPGIP may influence inhibitor activity.

The inhibition of pathogen PGs by PGIP in vitro suggests that in planta PGIP is a deterrent to pathogen degradation of plant cell walls. PGIP expression can be induced by several pathogen and wound-related processes in vegetative tissues of Phaseolus vulgaris and Glycine max (Bergmann et al. 1994; Favarone et al. 1994; Devoto et al. 1997, 1998) and in apple fruit (Yao et al. 1999), but the effect of induced PGIP expression on disease susceptibility has not been measured. However, in fruit from pear, raspberry, and tomato, in tomato flowers, and in bean pods, PGIPs are expressed in the absence of disease symptoms (Johnston et al. 1993; Stotz et al. 1993, 1994). The expression of tPGIP in the earliest stages of the immature developing fruit and in flower tissues suggests that expression of tPGIP may not require a signal arising from pathogen infections. In young, developing fruit, pre-existing tPGIP could limit the tissue colonization process by inhibiting pathogen PGs. Thus, in immature fruit, PGIP and other plant functions may contribute to the quiescent coexistence of the pathogen and developing fruit containing immature seeds. A similar function has been suggested for proteinase inhibitors in the defense of immature tomato fruit against insect predators (Pearce et al. 1988). As fruit ripen, decomposition of the cell wall by pathogens may be useful for the plant, because tissue breakdown would facilitate the release of mature seeds into the environment. In mature and ripening fruit less PGIP may be available to inhibit fungal PGs, and the consequent reduction of PG inhibition may be one factor that allows quiescent infections to develop on ripe fruit. Other factors, such as the availability of metabolizable substrates or the presence of other cell-wall-degrading enzymes produced by the pathogen or fruit, are also likely to contribute to disease development.

This is to our knowledge the first example that the heterologous expression of a protein in tomato successfully confers resistance against $B$. cinerea by targeting tissue-macerating functions of the fungus (Graham et al. 1996). Previously, another group has shown that an antifungal compound, resveratrol, synthesized by the expression of resveratrol synthase from grapevine, conferred partial resistance to $B$. cinerea in tobacco (Hain et al. 1993) but not in tomato (Thomzik et al. 1997). Strategic modifications of the amino acids of PGIPs and the transgenic expression of the modified PGIPs as well as native PGIPs from other plant sources may prove to be a fruitful source of inhibitors of fungal virulence functions that specifically reduce the aggressiveness of tissue degradation by the pathogen.

The expression of pPGIP in transgenic plants illustrates that one among many defense factors present in green fruit, a tissue that is not a robust host for pathogens, can be added to other host tissues to reduce their susceptibility to a pathogen. Thus, augmenting plant defenses against pathogens by increasing plant inhibitors of pathogen virulence functions may reduce the tissue-degradative processes of fungal pathogenesis. The use of transgenic plants with reduced $B$. cinerea susceptibility may diminish the use of pesticides and chemical treatments, which are, thus far, still the most commonly applied methods for combating gray mold.

\section{MATERIALS AND METHODS}

Construction of transgenic tomato over-expressing pPGIP.

The coding sequence for pPGIP, including the $\mathrm{N}$ terminal signal sequence, was linked to the CaMV $35 \mathrm{~S}$ promoter and the TMV U1 $\Omega$ enhancer by creating an $N$ coI site at the translational start with the mutagenic primer TCAACCGGTACCAAAACCATGGAACTCA. The expression cassette included the Nos terminator. After ligation, the pPGIP coding sequence was confirmed by nucleic acid sequencing. The expression cassette was introduced into pBIN19 containing the NPTII selectable marker expressed with the CaMV $35 \mathrm{~S}$ promoter and introduced into Agrobacterium tumefaciens. After co-cultivation with Lycopersicon esculentum cv. T5 cotyledon explant sections (Fillatti et al. 1987), transformed tissue was selected with kanamycin and intact plants regenerated. Individuals with single-copy inser- 


\section{\begin{tabular}{|l|l|}
\hline \multicolumn{2}{|c|}{ Control plant } \\
\hline B05.10 & $\Delta B c p g 1$ \\
\hline
\end{tabular}}

\begin{tabular}{|c|c|}
\hline \multicolumn{2}{|c|}{$\begin{array}{c}\text { PGIP-expressing } \\
\text { transgenic plant }\end{array}$} \\
\hline B05.10 & $\Delta B c p g 1$ \\
\hline
\end{tabular}
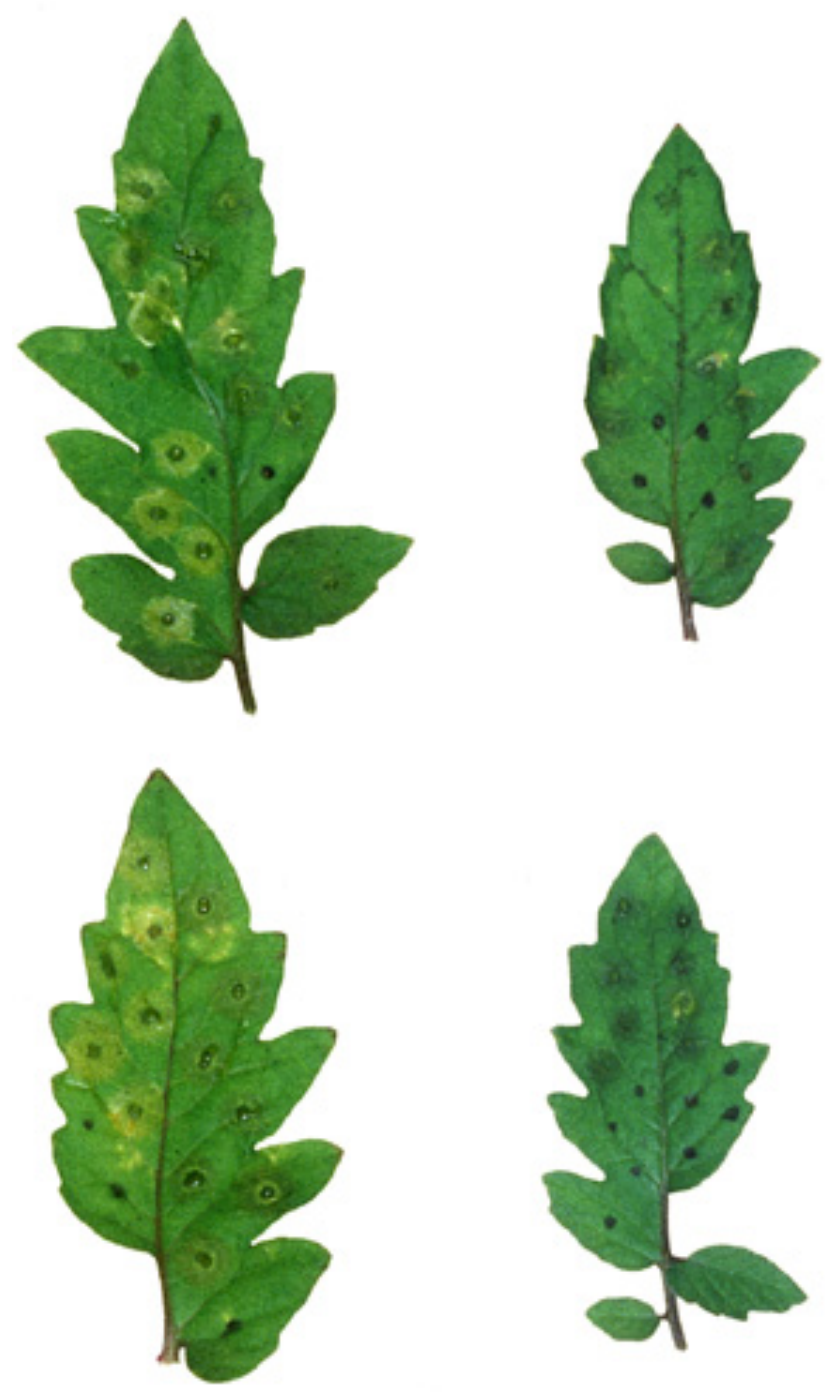

Fig. 6. Botrytis cinerea colonization of control and transgenic tomato leaves. Duplicate detached, untransformed, segregant control (2-3-34) and homozygous transgenic (2-3-11) leaves were inoculated with $2-\mu 1$ droplets of conidia of $B$. cinerea B05.10 (left leaf half) and the Bcpg1 deficient mutant strain (right leaf half) and observed after 7 days at $4^{\circ} \mathrm{C}$. Responses on two leaves from untransformed segregant (left, 2-3-34) plants and two leaves from transgenic (right, 2-3-11) plants are shown. tions detected by Southern analysis of genomic DNA and high levels of pPGIP expression, observed by Western analysis of extracted cell wall proteins, were selected for further analysis. Homozygous, heterozygous, and untransformed, segregant progeny were identified by Southern analysis and segregation of the genotype in progeny in subsequent generations. Suspension cultures were established from the homozygous transgenic line, 2-3-11, and the untransformed segregant line, 2-334 , by transferring callus developed from cut cotyledons grown on MST medium with agar (MST medium: $1 \times$ MS [Murashige-Skoog] salts, $1 \times$ Nitsch's vitamins, $0.1 \mathrm{mg}$ of benzyl adenine per liter, $2 \mathrm{ml}$ of (2,4-dichlorophenoxy)acetic acid (2,4-D) per liter, $0.8 \%$ agar, $\mathrm{pH} 5.8)$ to liquid MST medium. Flasks $(500 \mathrm{ml})$ containing $70 \mathrm{ml}$ of MST medium were transferred weekly with 20 to $50 \mathrm{ml}$ of a week-old suspension culture, and shaken at 80 to $130 \mathrm{rpm}$ (model 3590; LabLine Equipment, Melrose Park, IL) with a 12 -h light cycle at $25^{\circ} \mathrm{C}$.

\section{Northern analysis.}

RNA was purified from vegetative and fruit tissues from plants grown in the greenhouse using standard procedures (Dong et al. 1991). Fruit were collected at the indicated stages as determined by visual observation of fruit size and the exterior and interior color of the pericarp tissue. Total RNA (15 $\mu \mathrm{g})$ was separated by agarose gel electrophoresis, transferred to Hybond $\mathrm{N}$ membranes, and hybridized to random primed ${ }^{32} \mathrm{P}$-labeled probes. The $t P G I P$ probe was a 1,038 -bp DraIII fragment of $t P G I P$ and the $p P G I P$ probe was a 1,070-bp SpeI/NotI fragment of $p P G I P$ (Stotz et al. 1993, 1994). The blots were hybridized at $42^{\circ} \mathrm{C}$ in $5 \times$ SSPE $(20 \times$ SSPE: $3 \mathrm{M}$ $\mathrm{NaCl}, 0.2 \mathrm{M} \mathrm{NaH}_{2} \mathrm{PO}_{4}, 0.02 \mathrm{M} \mathrm{Na}_{2}$ EDTA), $50 \%$ formamide, $0.2 \%$ SDS, $1 \times$ Denhardt's solution (100× Denhardt's: $20 \mathrm{~g}$ of Ficoll per liter, $20 \mathrm{~g}$ of polyvinylpyrrolidone per liter, $20 \mathrm{~g}$ of bovine serum albumin per liter), and $0.2 \mathrm{ml}$ of denatured sheared salmon sperm DNA per ml. Blots were washed twice at $42^{\circ} \mathrm{C}$ for $20 \mathrm{~min}$ each in $1 \times \mathrm{SSC}, 0.1 \% \mathrm{SDS}$, twice at $42^{\circ} \mathrm{C}$ for $20 \mathrm{~min}$ each in $0.2 \times \mathrm{SSC}, 0.1 \% \mathrm{SDS}$, and once for $35 \mathrm{~min}$ at $50^{\circ} \mathrm{C}$ in $0.1 \times \mathrm{SSC}, 0.1 \% \mathrm{SDS}$. Blots were exposed to film (X-OMAT with intensifying screens) and the extent of hybridization was based on the intensity of the exposure.

\section{Western analysis.}

Proteins were prepared by homogenizing tissues in 2 to 5 volumes of $1 \mathrm{M} \mathrm{NaCl}, 0.1 \mathrm{M} \mathrm{NaAcetate,} \mathrm{pH} 6,1 \%$ polyvinylpyrrolidone- $40,0.2 \%$ NaBisulfite, and extracting the material overnight with agitation at $0^{\circ} \mathrm{C}$. Debris was removed by centrifugation and proteins were precipitated with 2 volumes cold acetone. Approximately $50 \mu \mathrm{g}$ of total proteins was

Table 2. Lesion size at $4^{\circ} \mathrm{C}$ on transgenic and control plants inoculated with wild type and mutant $B$. cinerea strains

\begin{tabular}{|c|c|c|c|c|c|c|c|c|}
\hline \multirow[b]{2}{*}{ Experiment } & \multicolumn{2}{|c|}{ Control 2-16-14 ${ }^{\mathrm{a}}$} & \multicolumn{2}{|c|}{ Transgenic 2-16-27 } & \multicolumn{2}{|c|}{ Control 2-3-34 ${ }^{a}$} & \multicolumn{2}{|c|}{ Transgenic $2-3-11^{a}$} \\
\hline & Wt & $\Delta$ pg1 & Wt & $\Delta$ pg1 & Wt & $\Delta$ pg1 & Wt & $\Delta$ pg1 \\
\hline Exp $2(08 / 98)$ & $\begin{array}{c}5.3 \pm 1.8 \\
(184)(100 \%)\end{array}$ & $\begin{array}{c}4.0 \pm 1.1 \\
(185)(76 \%)\end{array}$ & $\begin{array}{c}4.7 \pm 1.2 \\
(140)(88 \%)\end{array}$ & $\begin{array}{c}3.5 \pm 0.8 \\
(138)(66 \%)\end{array}$ & $\begin{array}{c}6.0 \pm 1.3 \\
(178)(100 \%)\end{array}$ & $\begin{array}{c}4.1 \pm 0.9 \\
(179)(68 \%)\end{array}$ & $\begin{array}{c}4.6 \pm 1.1 \\
(169)(77 \%)\end{array}$ & $\begin{array}{c}3.6 \pm 0.7 \\
(169)(60 \%)\end{array}$ \\
\hline Exp 3 (11/98) & $\begin{array}{c}3.4 \pm 1.2 \\
(77)(100 \%)\end{array}$ & $\begin{array}{l}2.8 \pm 0.5 \\
(76)(84 \%)\end{array}$ & $\begin{array}{c}2.6 \pm 0.8 \\
(81)(76 \%)\end{array}$ & $\begin{array}{c}2.7 \pm 0.6 \\
(88)(78 \%)\end{array}$ & $\begin{array}{c}4.3 \pm 1.3 \\
(124)(100 \%)\end{array}$ & $\begin{array}{c}3.4 \pm 0.8 \\
(124)(79 \%)\end{array}$ & $\begin{array}{c}3.6 \pm 1.1 \\
(125)(84 \%)\end{array}$ & $\begin{array}{c}3.3 \pm 0.7 \\
(128)(77 \%)\end{array}$ \\
\hline Exp $4(05 / 99)$ & $\begin{array}{c}7.6 \pm 1.8 \\
(92)(100 \%)\end{array}$ & $\begin{array}{c}6.6 \pm 1.2 \\
(87)(86 \%)\end{array}$ & $\begin{array}{c}5.1 \pm 1.2 \\
(62)(66 \%)\end{array}$ & $\begin{array}{c}4.9 \pm 0.9 \\
(72)(64 \%)\end{array}$ & $\begin{array}{c}8.3 \pm 1.8 \\
(92)(100 \%)\end{array}$ & $\begin{array}{c}6.9 \pm 1.5 \\
(90)(83 \%)\end{array}$ & $\begin{array}{c}6.3 \pm 1.6 \\
(86)(76 \%)\end{array}$ & $\begin{array}{c}6.1 \pm 1.6 \\
(87)(74 \%)\end{array}$ \\
\hline
\end{tabular}

${ }^{a}$ Each leaf was inoculated on two leaflets. Each leaflet was inoculated on one half with the wild-type strain B05.10 (Wt) and on the opposite half with the Bcpg1 gene replacement mutant strain ( $\Delta \mathrm{pg} 1$, ten Have et al. 1998). Sizes of lesions expanding beyond inoculation sites were determined 7 to 10 days post inoculation. Averages of lesion sizes are given in $\mathrm{mm} \pm$ standard deviation. Numbers in parentheses are expanding lesions that were measured. Percentages are relative to lesion size of the wild-type strain on the control plant. 
separated by $10 \%$ SDS-PAGE and electro-transferred onto polyvinyl difluoride (PVDF) membranes. A polyclonal antibody to denatured purified pPGIP was used for Western detection of pPGIP (Stotz et al. 2000). The secondary antibodies conjugated with alkaline phosphatase were used to visualize the reacting proteins. Total proteins were detected on gels by staining with Coomassie blue or standard silver stain reagents. Gels were dried between cellophane sheets prior to photography.

To partially purify PGIPs, proteins were adjusted to $0.1 \mathrm{M}$ NaAcetate, pH 6, $1 \mathrm{M} \mathrm{NaCl}, 1 \mathrm{mM} \mathrm{CaCl}, 1 \mathrm{mM} \mathrm{MgCl}_{2}, 1$ $\mathrm{mM} \mathrm{MnCl}{ }_{2}$ (Con A buffer) and applied to a column containing Concanavalin A-Sepharose 4B. Proteins were eluted with 250 $\mathrm{mM} \alpha$-methyl mannoside in the Con A buffer. PGIPs were assayed for PG inhibition activity and characterized by Western analysis of eluted fractions. Partially purified PGIPs were deglycosylated by TFMS chemical cleavage (Edge et al. 1981; Karp et al. 1982).

\section{PGIP activity assay.}

The inhibition of the endo-PG activity from culture filtrates of $B$. cinerea Del 11 grown in glucose-containing Czapek medium (Sharrock and Labavitch 1994) was determined by radial diffusion assay in agarose (Taylor and Secor 1988). The diameters of zones cleared of the PG substrate, citrus polypectate (Sigma, St. Louis, MO), were compared with those for assays with known dilutions of the inhibited fungal endo-PGs used and the amount of inhibitor activity was based on these dilutions. A standard reducing sugar assay (Gross 1982) was used with samples in which the endogenous sugars had been removed by dialysis. To inactivate the endogenous fruit PG activity, extracts were heated to $70^{\circ} \mathrm{C}$ for $10 \mathrm{~min}$ and interfering endogenous carbohydrate substrate was removed by extensive dialysis (Tucker et al. 1980).

\section{Inoculation of fruit.}

Ripe fruit were collected from the progeny of four transgenic plants after self-pollination. The plants were grown in greenhouses. Fruit were surface sterilized with $10 \%$ hypochlorite for $20 \mathrm{~min}$ followed by repeated washing in distilled water at room temperature. Fruit were punctured to a depth of $1 \mathrm{~mm}$ with the tip of a disposable micropipette at four or five locations on the shoulder of each fruit. Conidia were collected by water washes of week-old sporulating cultures of the fungus grown on potato dextrose agar plates in reduced light at $25^{\circ} \mathrm{C}$. Ten microliters of an aqueous suspension containing $10^{3}$ conidia of B. cinerea var. Del 11 was placed in all but one of the puncture sites. A single control puncture wound on each fruit was mock inoculated with $10 \mu \mathrm{l}$ of water. Fruit were maintained in humidified plastic crispers at $15^{\circ} \mathrm{C}$ for 3 days in reduced light. The diameter of the macerated zone around each site of inoculation was measured with calipers and evidence of active fungal growth was assessed visually. Wound sites were considered to be uninfected if no evidence of tissue softening was observed $>1 \mathrm{~mm}$ outside of the wound site and if no significant amount of fungal hyphae was seen within the wound. Statistical analysis was done with two-way ANOVA. Angular transformation with correction of zeros and ones was done (Snedecor and Cochran 1980); these transformations had no effect on tests of significance and untransformed results are presented. Calculated standard errors of the means are indicated on the bar graph.
Inoculation of detached leaves and disease assessment.

Transgenic and control plants were grown in a greenhouse compartment under controlled temperature and humidity conditions. Fully developed composite leaves of 6- to 8-week-old plants were used for inoculation. Leaves were detached with a scalpel blade and inserted into wet florist's foam in a petri dish. Two leaves (one from the transgenic plant, the other from the control) were positioned together in a plastic box. The box contained wet filter paper on the bottom to maintain a high humidity, and a plastic grid was placed over the wet paper, to minimize direct surface contact of leaves with water. The lid of the box was transparent.

Two isolates of B. cinerea, wild-type (B05.10) and the mutant $\Delta B c p g 1$ (ten Have et al. 1998), were grown on plates until sporulation. Conidia were collected from sporulating cultures and inoculum was prepared as described by Benito et al. (1998). Eight to $102-\mu$ d droplets containing $10^{3}$ conidia were placed on leaflets of the detached composite leaves without wounding the surface. On each leaflet, one half was inoculated with the wild-type strain, B05.10, the other half was inoculated with the $\Delta B c p g 1$ mutant strain. In each experiment, 20 leaves of each plant genotype were inoculated. Ten inoculated leaves from control or transgenic plants were placed in boxes either at $20^{\circ} \mathrm{C}$ under daylight or at $4^{\circ} \mathrm{C}$ in darkness. Disease progress was followed and scored as described by Benito et al. (1998) and ten Have et al. (1998). At $20^{\circ} \mathrm{C}$, the proportion of expanding lesions was determined for each of the two strains on either the control plant or the transgenic plant 4 days after inoculation. The size of the lesions was not measured, since this depended largely on the moment of initiation of lesion expansion. At $4^{\circ} \mathrm{C}$, the lesions expanded approximately evenly. The lesion diameter (in $\mathrm{mm}$ ) was measured at 7 to 9 days after inoculation. Inoculations of fruit from control and transgenic tomato plants with the B05.10 and $\Delta B c p g 1$ have not yet been attempted. Leaf inoculations with the Del 11 strain were unsuccessful.

Statistical analysis of the results was carried out with a twoway ANOVA. For the tests carried out at $4^{\circ} \mathrm{C}$, leaflets in which less than half of the lesions eventually expanded were discarded from the analysis.

\section{ACKNOWLEDGMENTS}

We acknowledge the helpful assistance of Guy D'Hallewin, Piero Tonutti, Robin Emig, Henrik Stotz, Doug Shaw. and Keith Sharrock, and the thoughtful editing by the reviewers. We gratefully acknowledge the assistance of Rick Lubbers (WU Unifarm) in carefully growing the tomato plants for the disease assays.

\section{LITERATURE CITED}

Abu-Goukh, A. A., Strand, L. L., and Labavitch, J. M. 1983. Developmentrelated changes in decay susceptibility and polygalacturonase inhibitor content of 'Bartlett' pear fruit. Physiol. Plant Pathol. 23:101-109.

Baker, B., Zambryski, P., Staskawicz, B., and Dinesh-Kumar, S. P. 1997. Signaling in plant-microbe interactions. Science 276:726-733.

Benito, E. P., ten Have, A., van't Klooster, J. W., and van Kan, J. A. L. 1998. Fungal and plant gene expression during synchronized infection of tomato leaves by Botrytis cinerea. Eur. J. Plant Pathol. 104:207-220.

Bergmann, C. W., Ito, Y., Singer, D., Albersheim, P., Darvill, A. G., Benhamou, N., Nuss, L., Salvi, G., Cervone, F., and De Lorenzo, G. 1994. Polygalacturonase-inhibiting protein accumulates in Phaseolus vulgaris L. in response to wounding, elicitors and fungal infection. Plant J. 5:625-634.

Cervone, F., De Lorenzo, G., Pressey, R., Darvill, A. G., and Alber- 
sheim, P. 1989. Host-pathogen interactions. XXXIII. A plant protein converts a fungal pathogenesis factor into an elicitor of plant defense responses. Plant Physiol. 90:542-54.

Cook, B. J., Clay, R. P., Bergmann, C. W., Albersheim, P., and Darvill, A. G. 1999. Fungal polygalacturonases exhibit different substrate degradation patterns and differ in their susceptibilities to polygalacturonase-inhibiting proteins. Mol. Plant-Microbe Interact. 12:703-711.

Darvill, A., Augur, C., Bergmann, C., Carlson, R. W., Cheong, J.-J., Eberhard, S., Hahn, M. G., Ló, V.-M., Marfà, V., Meyer, B., Mohnen, D., O’Neill, M. A., Spiro, M. D., van Halbeek, H., York, W. S., and Albersheim, P. 1992. Oligosaccharins - Oligosaccharides that regulated growth, development and defense responses in plants. Glycobiology 2:181-198.

De Lorenzo, G., Cervone, F., Bellincampi, D., Caprari, C., Clark, A. J., Desiderio, A., Devoto, A., Forrest, R., Leckie, F., Nuss, L., and Salvi, G. 1994. Polygalacturonase, PGIP and oligogalacturonides in cell-cell communication. Biochem. Soc. Trans. 22:394-397.

Desiderio, A., Aracri, B., Leckie, F., Mattei, B., Salvi, G., Tigelaar, H., Van Roekel, J. S. C., Baulcombe, D. C., Melchers, L. S., De Lorenzo, G., and Cervone, F. 1997. Polygalacturonase-inhibiting proteins (PGIPs) with different specificities are expressed in Phaseolus vulgaris. Mol. Plant-Microbe Interact. 10:852-860.

Devoto, A., Clark, A. J., Nuss, L., Cervone, F., and De Lorenzo, G. 1997. Developmental and pathogen-induced accumulation of transcripts of polygalacturonase-inhibiting protein in Phaseolus vulgaris L. Planta 202:284-292.

Devoto, A., Leckie, F., Lupotto, E., Cervone, F., and De Lorenzo, G. 1998. The promoter of a gene encoding a polygalacturonaseinhibiting protein of Phaseolus vulgaris L. is activated by wounding but not by elicitors or pathogen infection. Planta 205:165-174.

Dong, J. G., Kim, W. T., Yip, W. K., Thompson, G. A., Li, L., Bennett, A. B., and Yang, S. F. 1991. Cloning of a cDNA encoding 1aminocyclopropane-1-carboxylate synthase and expression of its mRNA in ripening apple fruit. Planta 185:38-45.

Edge, A. S. B., Faltynek, C. R., Hof, L., Reichert, L. E., and Weber, P. 1981. Deglycosylation of glycoproteins by trifluoromethanesulfonic acid. Anal. Biochem. 118:131-137.

Elad, Y., and Evensen, K. 1995. Physiological aspects of resistance to Botrytis cinerea. Phytopathology 85:637-643.

Favarone, F., D’Ovidio, R., Porceddu, E., and Alghisi, P. 1994. Purification and molecular characterization of a soybean polygalacturonaseinhibiting protein. Planta 195:80-87.

Fillatti, J. J., Kiser, J., Rose, B., and Comai, L. 1987. Efficient transformation of tomato and the introduction and expression of a gene for herbicide tolerance. Pages 199-210 in: Tomato Biotechnology. D. Nevins and R. Jones, eds. Alan R. Liss, New York.

Gallie, D. R., Sleat, D. E., Watts, J. W., Turner, P. C., and Wilson, T. M. A 1987. The 5'-leader sequence of tobacco mosaic virus RNA enhances the expression of foreign gene transcripts in vitro and in vivo. Nucleic Acids Res. 15:3257-3273.

Graham, J., Gordon, S. C., and Williamson, B. 1996. Progress towards the use of transgenic plants as an aid to control soft fruit pests and diseases. Pages 777-782 in: Brighton Crop Protection Conference: Pests \& Diseases. Vol. 3. British Crop Protection Council (BCPC), Farnham, England.

Gross, K.C. 1982. A rapid and sensitive spectrophotometric method for assaying polygalacturonase using 2-cyanoacetamide. Hortic. Sci. 17: 933-034.

Hain, R., Reif, H. J., Krause, E., Langebartels, R., Kindl, H., Vornam, B., Wiese, W., Schmelzer, E., and Schreier, P. H. 1993. Disease resistance results from foreign phytoalexin expression in a novel plant. Nature 361:153-156.

Johnston, D. J., Ramanathan, V., and Williamson, B. 1993. A protein from immature raspberry fruits which inhibits endopolygalacturonases from Botrytis cinerea and other micro-organisms. J. Exp. Bot. 44:971-976.

Johnston, D. J., and Williamson, B. 1992. Purification and characterisation of four polygalacturonases from Botrytis cinerea. Mycol. Res. 96: 343-349.

Johnston, D. J., Williamson, B., and McMillan, G. P. 1994. The interaction in planta of polygalacturonases from Botrytis cinerea with a cell wall-bound polygalacturonase-inhibiting protein (PGIP) in raspberry fruits. J. Exp. Bot. 45:1837-1843.

Karp, D. R., Atkinson, J. P., and Shreffler, D. C. 1982. Genetic variation in glycosylation of the fourth component of murine complement. J.
Biol. Chem. 257:7330-7335.

Leckie, F., Mattei, B., Capodicasa, C., Hemmings, A., Nuss, L., Aracri, B., De Lorenzo, G., and Cervone, F. 1999. The specificity of polygalacturonase-inhibiting protein (PGIP): A single amino acid substitution in the solvent-exposed beta-strand/beta-turn region of the leucine-rich repeats (LRRs) confers a new recognition capability. EMBO J. 18:2352-2363.

Leone, G. 1990. In vivo and in vitro phosphate-dependent polygalacturonase production by different isolates of Botrytis cinerea. Mycol Res. 94:1039-1045

Pearce, G., Ryan, C. A., and Liljegren, D. 1988. Proteinase inhibitors I and II in fruit of a wild tomato species: Transient components of a mechanism for defense and seed dispersal. Planta 175:527-531.

Powell, A. L. T., Stotz, H. U., Labavitch, J. M., and Bennett, A. B. 1994 Glycoprotein inhibitors of fungal polygalacturonases. Pages 399-402 in: Advances in Molecular Genetics of Plant-Microbe Interactions. M. J. Daniels, J. A. Downie, and A. E. Osbourn, eds. Kluwer Academic Pub., Dordrecht, The Netherlands.

Sharrock, K. R., and Labavitch, J. M. 1994. Polygalacturonase inhibitors of Bartlett pear fruits: differential effects on Botrytis cinerea polygalacturonase isozymes, and influence on products of fungal hydrolysis of pear cell walls and on ethylene induction in cell culture. Physiol. Mol. Plant Pathol. 45:305-319.

Snedecor, G. W., and Cochran, W. G. 1980. Statistical Methods. 7th ed. The Iowa State University Press, Ames.

Staskawicz, B. J., Ausubel, F. J., Baker, B. J., Ellis, J. G., and Jones, J. D. G. 1995. Molecular genetics of plant disease resistance. Science 268:661-667.

Stotz, H. U., Powell, A. L. T., Damon, S. E., Greve, L. C., Bennett, A. B., and Labavitch, J. M. 1993. Molecular characterization of a polygalacturonase inhibitor from Pyrus communis L. cv. 'Bartlett.' Plant Physiol. 102:133-138.

Stotz, H. U., Contos, J. J. A., Powell, A. L. T., Bennett, A. B., and Labavitch, J. M. 1994. Structure and expression of an inhibitor of fungal polygalacturonases from tomato. Plant Mol. Biol. 25:607-617.

Stotz, H. U., Bishop, J. G., Bergmann, C. W., Koch, M., Albersheim, P. Darvill, A. G., and Labavitch, J. M. 2000. Identification of target amino acids that affect interactions of fungal polygalacturonases and their plant inhibitors. Physiol. Mol. Plant Pathol. 56:117-139.

Taylor, R. J., and Secor, G. A. 1988. An improved diffusion assay for quantifying the polygalacturonase content of Erwinia culture filtrates. Phytopathology 78:1101-1103

ten Have, A., Mulder, W., Visser, J., and van Kan, J. A. L. 1998. The endopolygalacturonase gene Bcpg1 is required for full virulence of Botrytis cinerea. Mol. Plant-Microbe Interact. 11:1009-1016.

Thomzik, J. E., Stenzel, K., Stocker, R., Schreier, P. H., Hain, R., and Stahl, D. J. 1997. Synthesis of a grapevine phytoalexin in transgenic tomatoes (Lycopersicon esculentum mill.) conditions resistance against Phytophthora infestans. Physiol. Mol. Plant Pathol. 51:265-278.

Toubart, P., Desiderio, A., Salvi, G., Cervone, F., Daroda, L., De Lorenzo, G., Bergmann, C., Darvill, A. G., and Albersheim, P. 1992. Cloning and characterization of the gene encoding the endopolygalacturonaseinhibiting protein (PGIP) of Phaseolus vulgaris L. Plant J. 2:367-373.

Tucker, G. A., Robertson, N. G., and Grierson, D. 1980. Changes in polygalacturonase isoenzymes during the 'ripening' of normal and mutant fruit. Eur. J. Biochem. 112:119-124.

Van der Cruyssen, G., De Meester, E., and Kamoen, O. 1994. Expression of polygalacturonases of Botrytis cinerea in vitro and in vivo. Meded. Fac. Landbouwk. Toegep. Biolog. Wetensch. Univ. Gent 59:895-905.

Wubben, J. P., Mulder, W., ten Have, A., van Kan, J. A. L., and Visser, J. 1999. Cloning and partial characterization of the endopolygalacturonase gene family from Botrytis cinerea. Appl. Environ. Microbiol. 65: 1596-1602.

Wubben, J. P., ten Have, A., van Kan, J. A. L., and Visser, J. 2000 Regulation of endopolygalacturonase gene expression in Botrytis cinerea by galacturonic acid, ambient $\mathrm{pH}$ and carbon catabolite repression. Curr. Genet. 37:152-157.

Yao, C., Conway, W. S., and Sams, C. E. 1995. Purification and characterization of a polygalacturonase-inhibiting protein from apple fruit. Phytopathology 85:1373-1377.

Yao, C. L., Conway, W. S., Ren, R., Smith, S., Ross, G. S., and Sams, C. E. 1999. Gene encoding polygalacturonase inhibitor in apple fruit is developmentally regulated and activated by wounding and fungal infection. Plant Mol. Biol. 39:1231-1241. 